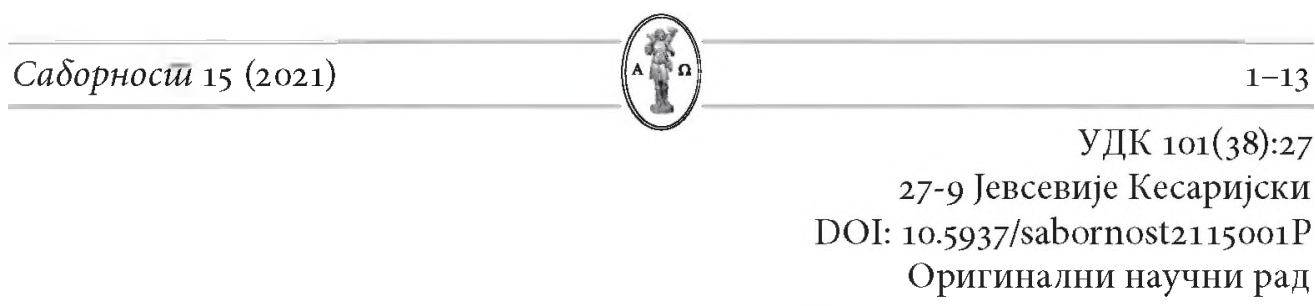

\title{
Predrag Petrović
}

University of Belgrade, Faculty of Orthodox Theology, Belgrade

\section{Testimony of Eusebius of Caesarea on the origin of hellenic philosophy}

\begin{abstract}
Adjective Hellenic represents the usual national determinant for the overall philosophical thought of the ancient world. Hellenes' commitment to recording philosophical thoughts and historical events is really fascinating, but deeply problematic. We have noticed that the ancient writers dealt incomparably more with the originality of the so-called Hellenic thought than the official representatives of the present-day science do. In the writings of Eusebius of Caesarea, we witness a special commitment to this topic, which is why we cite his testimonies collected not only from Christian writings, but also from philosophical sources and traditions still alive in his time. From the attached material we can conclude that the adjective Hellenic may be called into question in the final determination of the origin of the basic philosophical principles of the ancient world. We find it useful to point out the present-day problematic use of the phrase Hellenic philosophy as to the domesticated terminus tehnicus (like the "ancient Greeks"). In the background of the mentioned syntagm, we recognize the centuries long attempt to impose a certain life paradigm in trying to change life orientation among our people, too. At this historical moment when the Christological paradigm of existence is being most seriously questioned, we must be aware of every spiritual and historical change that has occurred as a result of our insufficient ecclesiology, which has opened the way to insufficiently verified "facts" about God, man and the world around us.
\end{abstract}

Key words: philosophy, myth, Hellenes, Orpheus, Aphrodite, Egypt, Babylon, city-state.

\section{Introduction}

In the broadest sense, today the term "Hellenic philosophy" implies a kind of a 1 development of the philosophical thinking of the ancient Hellenes, the subject of whose research is the nature of the world and the meaning of human existence in it. Books on the history of philosophy mainly try to present Hellenic philosophy as a peaceful and consistent development of learning about the physical and metaphysical world, as well as about man's place in it. This, we would say, idyllic attitude towards the development of the so-called ${ }^{1}$ Hellenic philosophy implies

ppetrovic@bfspc.bg.ac.rs

- In the following text, whenever we use the phrase "Hellenic philosophy", we shall consider it as if an adjective so-called is written before it and further elaboration of the topic will explain why. 
2 | Petrovic, P., Testimony of Eusebius of Caesarea on the origin of hellenic philosophy

the scientific research of philosophers and, consequently, the acquired knowledge of the "ultimate causes of things" which some have brought under Aristotle's First Philosophy (cf. Zeller, 1881, 3). It is indicative that such idyllic didactics about the ancient "Hellenic" world as the basis of cultural civilization is generally introduced to pupils in elementary schools in Serbia (cf. e.g. Đukanovic, 2012, 36-57) ${ }^{2}$. If we were to try to justify such an idyllic projection or perspective of philosophy, the first problem we would encounter would be precisely the (in)consistency of the overall philosophical thought as such. At this point, a question arises - is it possible to find two philosophers in the history of philosophy whose opinions overlap? The same question realistically opens the problem of the broader meaning of philosophy, which is based on diverse principles of existence. The significance of the historical legacy that we would sum up as philosophy certainly does not lie in a recapitulation of ideas presented long ago; in our opinion, they do not have any soteriological aspect in any previous, nor in the present historical moment. In that sense, the "development" of philosophical thought implies problematic contents that run parallel to the already traced history of philosophy and beyond those domesticated "facts" to which we are accustomed in the ideological approach to Hellenic philosophy (cf. Zeller, 1881, V).

Had philosophers supplemented each other with their individual teachings, we might have before us a more or less complete, consistent, and even useful didactic framework for natural and undoubtedly philosophical tradition on the example of the current historical moment, too. In contrast, Hellenic philosophers, by (over)taking ideas and teachings not only from other non-Hellenic traditions, but also from each other, adapting them to themselves and their "ear", presented same as their own, and left behind a disconnected set of ideas or teachings. Appropriation of other people's teachings implies that Hellenic authors historically do constantly mention the original sources of individual ideas that they (having been taken over) embedded in similar or dissimilar epistemological contexts. We bear in mind that there is a possibility that the same idea is sometimes inherited by two or more thinkers. However, these are individual historical phenomena, and not common historical facts. The takeover therefore does not refer to coinciding ideas that are somehow accidentally found in the works of two authors. What makes appropriating an idea problematic is the fact that there is no citation of the idea is unaccompanied, which would point to a legal takeover of the original idea ${ }^{3}$. The same applies to pointing to the original source of a tradition in the broader sense of the word, which we see as a problem in the Hellenic philosophy wherein we encounter historically persistent non-citation of the real authors of the appropriated idea, concept, or meaning. Of course, nobody talks about the wider historical context from which the tradition was appropriated. Taking over ideas, therefore, does not necessarily mean literally

2 We are talking about a history textbook for the 5 th grade of primary school.

3 Unfortunately, present time is full of such examples, too. 
plagiarizing sentences, although we come across testimonies like the one that Ephorus literally took over from Dimach, Callisthenes and Anaximenes as many

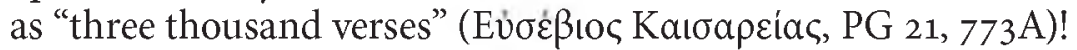

In order to focus more clearly on the seriousness of the problem in question, we will use the testimonies of authors who were historically closer, and sometimes contemporaries of some of the so-called. Hellenic philosophers. In that sense, we shall try to shed light on a different historical perspective that we consider important in the final positioning of the dubious attribute "Hellenic", as a "normal" national marking which, for certain reasons, has been ideologically attributed to the philosophical thought of ancient Greece. The author whose testimonies we will pay attention to is Eusebius Pamfilii (265-340), Bishop of ancient Palestine, a man of "Hellenic" education and great erudition, whose works today represent an indispensable research material for every researcher of world history, the history of The Church of Christ, as well as, in our opinion, the true origin of not only Hellenic philosophy but also Hellenic thought in general. Eusebius' sources refer not only to authors who were like-minded, but also to authors who were bitter opponents of Jewish and Christian thought, such as the Neoplatonist Porphyry (cf. $772 \mathrm{C}$ ). In addition to that fact, when he wanted to talk about Plato's philosophy, Eusebius referred precisely to the Platonists, who were such in their deepest conviction. One of them, Prosinius, at a gathering dedicated to Plato, spoke of Plato as the one who had taken ideas from other thinkers (cf. $780 \mathrm{~A} ; 845 \mathrm{~A}-849 \mathrm{~A}$ ). Therefore, both the argumentation and the conclusions that Eusebius brings certainly represent a respectable basis which we might question had Eusebius referred exclusively to Christian likeminded people. Of course, in the following text, we will pay attention to some other (ancient and modern) authors who have dealt with similar topics.

\section{Eusebius' postulates on the origin of Hellenic philosophy}

We begin Eusebius' testimonies with ${ }^{4}$ his tenth book of Gospel Preparations, in which he refers to Clement of Alexandria, who widely speaks of the Hellenic custom of appropriating other people's inventions and ideas. Clement does not hesitate to brand the Hellenic philosophers as thieves. He does not hide his position against such a status quo of his time, and perhaps sarcastically, yet possibly really with squalor, therefore, without sarcasm, he begins his review of this Hellenic "custom" with the words:

"My life would be ruined if I exposed in detail the Hellenic selfish thievery ( $\varphi$ i-

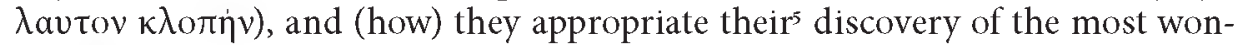
derful truths ( $\kappa \alpha \lambda \lambda i \sigma \tau \omega \nu \delta o \gamma \mu \alpha \dot{\tau} \omega v)$ which they (in fact also) took over from us"

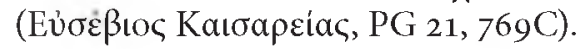

4 Eusebius begins his text called Gospel Preparation with testimonies about the origin of mythology among the Hellenes. To find out more on this topic, see Petrovic, 2020, 157-170.

5 These are the inventions of the so-called barbarian. 
4 | Petrovic, P., Testimony of Eusebius of Caesarea on the origin of hellenic philosophy

When speaking in the broadest context of the origins of ancient ideas and inventions concerning everyday life, Eusebius refers again to the writings of Clement of Alexandria, who testified that the skill of healing was invented by the Egyptian Apis, while he mentioned Atlas the Libyan as the first shipbuilder and navigator (ibid.). The Egyptians and Chaldeans were the first to speak about astrology, and the Cari people were the first to predict future events using the movement of stars $(789 \mathrm{C})$. The Phrygians were the first to tell fortune by watch-

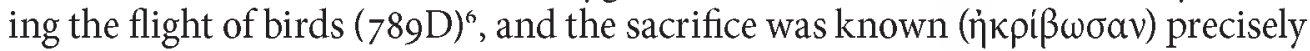
by the Tuscs, the neighbors of the Italians. The Isaurians and the Arabs could tell the future with the help of birds, and the Themisseians did so with the help of dreams (same). The Tyrrhenians invented the trumpet, and the Phrygians the flute. The Egyptians first invented the lamp and divided the year into twelve months $(789 \mathrm{D}-792 \mathrm{~A})^{7}$. The Egyptians also invented geometry. Temnis and Damnameneus discovered iron in Cyprus, and Hesiod testified that Scythian Delas invented bronze casting. The Thracians invented the curved sword (scimitar) and were the first to use shields on horses, while the Illyrians invented the shield. Kadmos the Phoenician invented stone cutting and discovered gold on Mount Pangeon (near today's Kavala). The Cappadocians found a navla, which was like a bichord, an Assyrian two-stringed instrument (792AB). The Kharkedons invented a boat with four oars, and the first such boat was built by Vosporus (792B). Medea from Colchis (present-day Georgia) was the first to invent hair dye. The Norops, the Peonians who are also called Noritsi invented copper processing. Olympus and Martius devised Lydian harmony. They were both Phrygians ( $789 \mathrm{D})$. Olympus invented notes, and Mars invented Phrygian, mixofrygian and mixolydian harmony (792 BC), while Dorian harmony was invented by Tamir, who was Thracian (792C). The Phrygian Satyr invented the double flute (792B). The Persians invented the chariot, the couch, and the desk, and the Sidonians invented the ship trireme. The Sikels found a kithara-like phorminx, as well as the castanets. During the reign of Semirama, Empress of Assyria, the making of clothes from fine linen began (792D-793A). Atossa, the ruler of Assyria, was the first to compose or write epistles (793A). Clement testifies that all this was exposed by Scamon of Mytilene, Theophrastus of Ephesus, Kidip of Mantineia, Andipan, Aristodimos, Aristotle, Philostefanus and Straton of Lampsacus (793A). Eusebius here quotes in a way Clement's summary of the previous section with the words: "(and) I have provided only some of them (testimonies) to show the nature invented by the barbarians and useful inventions, which the Greeks benefited from" (793A). We see that the historical gnoseological context is problematic when it comes to Hellenes, since there is evidence that many of them, wanting to create their own "history", did not know "who Kronos was and who

${ }_{6}$ Clement bears in mind not just a bird's flight, but a prediction of events in relation to the flight of birds.

7 The Egyptians were the first to ban intercourse with women in temples and a law obliged priests who were with women to wash before entering the sacral building $(792 \mathrm{~A})$. 
Bel was, and mistakenly thought that they worshiped Kronos, they worshiped Bel and the other way around. Others among them did not know who Kronos

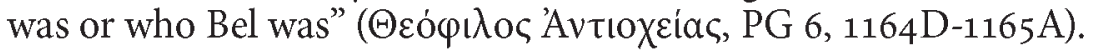

Diogenes Laertius was one of the authors who said that the Thracian Orpheus was the most ancient philosopher (cf. Diogenes, I, 5), and that the gymnosophists and druids expressed their philosophy in riddles (I, 6). Thanks to such testimonies, today we have authors such as Robert Graves, who speaks of the fact that the entire corpus of Greek mythology consists of content "imported from Crete, Egypt, Palestine, Phrygia, Babylonia and elsewhere" (Graves, 1955, 4-5). We have in mind the fact that the myth cannot be understood without pointing to a specific ethnographic context (cf. Levy-Strauss, 1991, 87), so that a mythological connection between Egypt and Siberia is possible, judging by the discoveries of the Siberian ongons (cf. Same, 17).

The next testimonies that Eusebius mentions are those of Titus Flavius Josephus who considers Hellenes to be a young people who utilised barbaric inventions. Eusebius' motive for quoting Joseph's testimonies lies in the need for "accurate and certain assurance of said (things)" (793AB). More than a century before Clement, Josephus Flavius testified to the no less topicality of the abovementioned Hellenic "custom", and to his rebellion against such a state of affairs, in the following words:

"First of all, I am completely astonished by those who think that we should pay attention to Hellenes regarding the oldest works and (that we should) learn the truth from them, and that we and other people should not be trusted. And I see the opposite case in everything, if we do not need to follow vain opinions, but take from the things themselves what is (right). Everything regarding the Hellenes is completely new, and as someone might say, they came to being yesterday or the day before yesterday, and I am talking about building cities, discovering skills, writing laws, and most of all their effort to compile histories" $(793 \mathrm{~B})^{8}$.

It is important to show one of Plato's passages from his Timaeus in which the Hellenic "ancient times" is spoken of in a very unusual way. Namely, Plato states:

"In Egypt... in the delta where the River Nile Divides, there is a city and district called Sais; the city was the birthplace of king Amasis, and is under the protection of the goddess Neith or Greek, as they call it Athene. The citizens have a friendly feeling toward the Athenians believing themselves to be related to them in a way. Hither came Solon, and was received with honour, and there he first learnt, by conversing with the Egyptian priests who were most informed about the matter, how ignorant he and his countrymen were of antiquity, if they knew anything

8 We cannot help but notice that even today the educational systems of the Western world maintain an identical state of affairs regarding the so-called ancient Greeks as in the time of Josephus Flavius (almost 2000 years). One gets the impression that only the Hellenes were important in the ancient world, while other peoples were scientifically, technologically, and historically generally, intellectually insufficiently adept, immature and therefore unreliable. Therefore, for us, it is indicative of Joseph's historical testimony, according to which in his time the memory of Hellenic recentness in the sense of civilization was not interrupted (cf. 793B). 
6| Petrovic, P., Testimony of Eusebius of Caesarea on the origin of hellenic philosophy

about them at all Perceiving this, and with the view of eliciting information from them, he told them the tales of Phoroneus and Niobe, and also of Deucalion and Pyrrha, how they survived the flood and he endeavoured to count the generations which had since passed, and summoned to memory the time that passed since, trying to determine their dates. Thereupon an aged priest said to him: 'O Solon, Solon, you Hellenes are ever young, and there is no old man who is a Hellene.' 'What do you mean?' Solon asked. 'In mind,' replied the priest, 'I mean to say that you are children; there is no opinion or tradition of knowledge among you which is white with age... And whatever happened either in your country or in ours, or in any other region of which we are informed - if there were any actions noble or great or in any other way remarkable, they have all been written down by us of old and are preserved in our temples. Whereas just when you and other nations are beginning to be provided with letters and the other requisites of civilized life, after the usual interval, the stream from heaven, like a pestilence, comes pouring down, and leaves only those of you who are destitute of letters and education; and so you have to begin all over again like children, and know nothing of what happened in ancient times, either among us or among yourselves As for those genealogies of yours which you just now recounted to us, Solon, they are no better than the tale for the children $(21 \mathrm{e}-23 \mathrm{~b})$.

We find special importance in Joseph's testimony about the survival, both until then, but also until now, of "Hellenic" sources. The area presently inhabited by the Greeks has survived so many different troubles and sufferings that the memories of the events of the past have dissipated over time. The Hellenic newcomers imposed themselves in that area as original authorities. Eusebius talks about the cataclysmic events that destroyed this part of the world after which, surprisingly, the events that describe the so-called Hellenic myths emerged. They were legends about the floods during Deucalion's times, and about horrible fires during the time of Paethon and of many other natural disasters of that time (cf. 809B) Eusebius cites the testimony of a historaian Africanxxx according to whom, after the cataclysm in the area that was then called Attica, there were no rulers for one hundred and eighty-nine years $(813 \mathrm{D}-816 \mathrm{~A})$.

"Just look", Joseph continues, "where and when it was that (the Hellenes) learned the nature of the letters" (793D), referring to the Phoenicians and Kadmos. The first to philosophize about heavenly and divine things were Ferekid the Syrian, Pythagoras, and Thales of Miletus, and "they all unanimously admitted that they had been taught by the Egyptians and the Chaldeans (and) that they had written little, and the Hellenes believe these (writings) to be (their) the oldest" (796B). According to Tatian's testimony, it was only after many generations

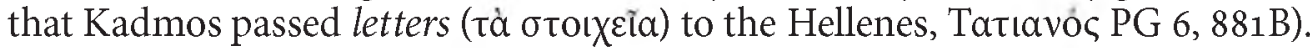
Theophilus of Antioch also testifies that the Hellenes became literate "recently

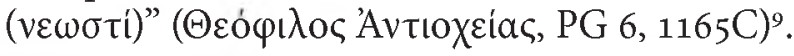

9 John Forsdyke cites examples of historical paradoxes such as those of Tacitus, that the Germans and the Retii had many monuments and tombs with Greek inscriptions or that the Gallic Druids used the Greek alphabet at the time of Julius Caesar (Forsdyke, 1956, 20). The most ancient men- 
Hellenes did not agree with each other even in their books, so they often described the same events in an opposing manner (796C). Thus, for example, Hellanicus disagreed with Acousilaos about genealogies, Acousilaos corrected Hesiod, Ephorus presented Hellanicus as a liar, as did Timaeus with Ephorus. Timaeus was challenged by those after him, and Herodotys was challenged by all. Timaeus disagreed with Antiochus and Philistus (796C), while Thucydides was considered to have plagiarised many a testimony (796D). As for the Athenians, they said of themselves that they were indigenous and that they had invented education. However, none of this can be found in writing, since the oldest of all of their written public documents are those written just before the period of $\mathrm{Pi}$ sistratus' tyranny in Athens (561-527) and were written by Draco and referred to the legal provisions related to murder $(797 \mathrm{AB})^{10}$.

After the presentation of Josephus Flavius, Eusebius cited the testimonies of Diodorus of Sicily collected in Diodorus' work. The Library. Diodorus considered "philosophers" - travellers to Egypt who aimed to learn and take over the education and laws important, and mentioned their names first, there $(797 \mathrm{D})$. Diodorus testifies that Egyptian priests recorded in their holy books the visits of Orpheus, Museus ${ }^{11}$, Melampus, Daedalus, Homer, Lycurgus of Sparta, Solon of Athens, Plato, Pythagoras of Samos, mathematician Eudoxus, Democritus of Abdera, and Enopidus of Chios (797D-80oA). Although Orpheus is known as a Cadmean, some have considered him a Hellene out of ignorance, and some purposefully, (97C). Diogenes Laertius stated that Orpheus was a Thracian (Diogenes, 1972, I, 5), while Diodorus of Sicily cited the testimony according to which Orpheus brought from Egypt "many secret rites and (everything) that (was) orgi-

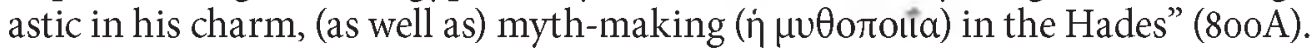
The Jewish historian Artapan of Alexandria testified to an ancient tradition that says that Moses was Orpheus' teacher (729A).

Orpheus brought in the rites from Egypt in such a way that the rite dedicated to Osiris was identical to the one dedicated to Dionysus, as was the case with the rite of Isis and Demetra. It was only a matter of changing the name in the rite (80o AB). Melampus brought from Egypt mythological stories about Kronos

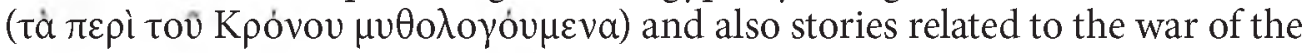
Titans, as well as all the suffering histories of the gods $(800 \mathrm{C})$. Homer changed the historical events that took place in connection with Egypt and described

tion of Homer's writings is the legend mentioned by Cicero, Pausanias and others, according to which Homer's writings were first scattered around and only later collected in the 6th century in Athens by Pisistratus. An earlier Greek version of the story mentions Hipparchus, the eldest son of Pisistratus, who was the first to bring cantos to Athens, which were recited at holy festivals ever since. The version of the story that places Homer's writings in the 6 th century is also justified by the recognition of Athenian elements in the language of these writings (ibid. 22).

10 Due to the cruelty of these punishments, we have a phrase draconian punishment.

1 Museus was the first to write theogonies, that is, genealogies of the gods, and spread the word that everything comes from one and that everything returns to one (cf. Diogenes, 1972, I, 3) 
them in his own way. So, for example, Helen received intoxicating medicine with which she caused Telemachus to faint in Menelaus' house so that he would forget about all the evils that had been done to him. Diodorus added that to that day that powerful medicine had been used since those ancient times as a medicine against anger and sorrow, and that it could only be found among the people of

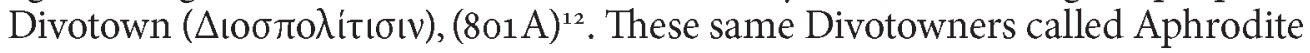
golden after their (Egyptian) tradition, and near Momemphis (near the Nile Delta) in Diodorus' time there was a field called Golden Aphrodite (801AB). Lycurgus, Plato, and Solon incorporated many of Egypt's customs into their laws. Pythagoras took from the Egyptians sacred word, theories of geometry, knowledge of numbers as well as teachings about the migration of human souls into animals (801BC). Clement stated that Heraclitus of Ephesus had stolen most of Orpheus' ideas, and Plato took over the teaching of the immortality of the soul from Pythagoras. Others took the same teaching from the Egyptians ${ }^{13}$. Democritus, who had studied Egyptian legends for five years, also took over Egyptian astrology, and Inopidus took over Egyptian priests' tales about the solar circle as well as about the curve that the Sun created with its movement $(801 \mathrm{C})$.

On the mutual intolerance of Hellenic thinkers, Diogenes Laertius stated that Socrates, listening to Plato read Lysia, stated, "By Heracles, how this young man lies a lot about me" (Diogenes, 1972, III, 43). Diogenes also testified that Plato was not on good terms with Aristotle, Aeschylus, and Idomenus, nor with Xenophon of Athens, his rival ${ }^{14}$, who, although he was a follower of Socrates,

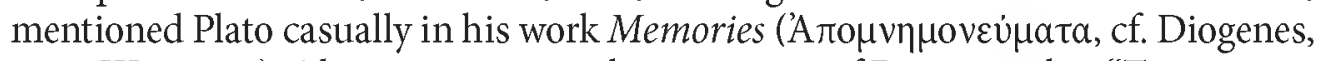
1972, III, 42-44). Also interesting is the testimony of Diogenes that "Timaeus in his ninth book of History claims that (Empedocles) was a student of Pythagoras and added that he was then caught stealing his lectures, so, like Plato, he was excluded from teaching at the school" (Diogenes, 1972, III, 55).

\section{An educational imperative in the logical perspective of the current state of affairs}

Citing arguments in favour of the problematic origin of the so-called Hellenic thought, we believe that one of the educational imperatives of our time should be to correct the way in which the educational system presents the philosophical heritage of the natives in Egypt, Chaldea, the Levant, Asia Minor, as well as the area that is currently within the borders of the Greek state. This educational imperative arises not only from the arguments put forward by learned people belonging to and not belonging to the Hellenic people, but precisely from the

12 Thebe and Divotown are one and the same city $(800 \mathrm{~A})$.

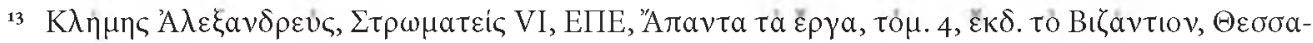

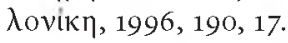

14 The rivalry stemed from the fact that they both noted down similar writings regarding Socrates' dialogues. 
testimonies of the Hellenes themselves about taking over truths, ideas, and opinions from ancient cultures in the mentioned areas. In our time, as well as two centuries earlier, Western philosophers have been strangely silent regarding this ordinary truth. In this respect, we shall ask a broader question to which the modern "enlightenment", which spreads its operational activities within the individual national educational systems of the Western world simply avoid to answer, and it is - Why have whole generations of a large part of humanity been held in lies and delusions? Let us just take Plato's concept of the state for example, that is, his favouring the social order of the so-called city ( $\dot{\eta} \pi \dot{\lambda} \lambda \mathrm{Ic})$ which is presented as a historical nucleus or paradigm of modern and a just and democratic social system in all the textbooks, not only the history of philosophy ones, but also the history books of the Old World. How come that the educational systems of the countries of the Western world have been favouring the historical "emergence" of the so-called city-state, and at the same time, at least for the sake of truth, they do not state a much more important historical fact? Namely, at the time when two or more Hellenic cities ${ }^{15}$ failed (or not wanted) to form a lasting common political, economic and social life, there were empires that stretched from the Danube in the North, India in the East and Ethiopia in the South, like the Achaemenid Empire (520-330) as the largest empire in the history of the Old World. We believe that it is fraudulent to justify the exceptional significance of the historical "endeavour" or "achievement" of the so-called city-state with the so-called democratic discourse, given the slave-owning character of Plato's essentially Orwellian form of government euphemistically shaped and presented as Plato's imaginary political fairy tale.

In modern times, we come across another ingrained opinion stating that the ancient Christians had a negative attitude towards mythology because it advocated idolatry and an indecent way of life, while not everyone had the same attitude regarding philosophy. Some rejected philosophy because it was unethical, opposing it to Christian attitudes and disagreement, while others were in favour

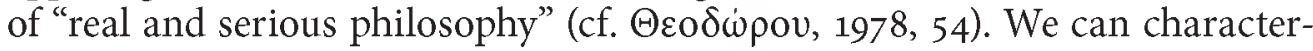
ize such views as "systemically correct" but insufficient in our search for those aspects of the problem nobody talks about, because they know something or nothing about it. It is as if it were an accepted social norm whose origin is not subject to examination.

In contrast to that, we must pay attention to yet another very important fact pointed out by Eusebius of Caesarea, which refers to the dependence of philosophy on mythology. Mythology and philosophy, due to different approaches to reality, may at first seem mutually incompatible areas, since reasoning as the basis of philosophy is much poorer than myth. Myth somehow becomes a higher gnoseological form since it encompasses language and art and science and often

15 We believe that a serious research is due on the topic of the so-called Hellenic cities and how people lived in them, as well as the origin of such ways of life. 
10 | Petrovic, P., Testimony of Eusebius of Caesarea on the origin of hellenic philosophy

ritual, simultaneously, and some authors consider it prelogical (cf. Segal, 2002, 34). Other authors, on the other hand, believe that Heraclitus, with his concept of logos, interrupted the previous "mythical" tradition, but he also continued it, since he systematically used elements of myth (cf. Zeleke, 2019, 182; 185). However, some authors believe that this is a certain dependent relationship or a connection between philosophy and mythology. For example, in Socrates, mythology and philosophy do not seem to be in conflict. The observation of one of the authors who dealt with this topic is focused on certain moments in Phaedo (6oe-61b) when Socrates combines music, poetry and the divine message, or when he says about the poet Euenus (61c): "Isn't Euenus a philosopher?" (Zhu, 2005,454 ), or again when he states that the philosophical discussion of death does not really differ from the speech about myths ( $\mu \nu \theta 0 \lambda$ o $\gamma \varepsilon i v$, cf. Ibid.), etc.

On the other hand, Graves treats the problem of the deeper inner connection of mythology and philosophy in a different way. Namely, he states the following:

"The myth of Zeus and Ganymede was very widespread in Greece and Rome, because it had within a religious justification for the passionate love of a mature man for a boy. Until then, sodomy was allowed only as the highest form of goddess worship. Cybele worshipers tried to achieve ecstatic unity with her by castrating themselves and dressing like women. Such a Sodomite clergy legally existed in the temples of the Great Goddess in Tyre, Iara, Hierapolis, and Jerusalem (I Kings XV, 12 and 2; Kings XXIII, 7). But the new passion, which, as Tamir says, was approved by Apollodorus (see 21, m), brings the victory of patriarchy over matriarchy. This gave Greek philosophers the opportunity for intellectual plays, which men could have fun with, now that they had discovered the possibilities of homosexual love without the presence of women. Plato used this and used the myth of Ganymede to justify his own sentimental feelings towards his students (Faidar 79); although he otherwise considered sodomy unnatural and called the myth of Zeus' submission to this vice 'an evil Cretan fabrication' (Laws I, 8). This was also supported by Stephen of Byzantium (sub Harpagia), who says that King Mino from Crete took Ganymede to be his friend in bed ('an order received from Zeus'). The consequences of the spread of Plato's philosophy were that Greek women, who were dominant in intellect, degenerated and gradually became unpaid workers and caregivers of children wherever Zeus and Apollo were the ruling gods" (Graves, 1955, 64).

Presenting all the historical circumstances and factors that influenced the emergence and development of philosophy as such would provide some basis for understanding philosophy really as a historical phenomenon that grew out of the non-Hellenic Devonia that the Hellenes appropriated as if they were always their original heritage. However, in the absence of all historical factors, philosophy is still considered an extraordinary phenomenon that arose in Asia Minor in response to man's alleged fundamental need to explain the world and his place in the world (cf. Marshall, 1891, 3). Philosophy thus begins with Thales and Anaximander (Ibid.). That is why opinions can often be heard about the great importance of philosophical education for the Christian faith, 
since such education provides us with a lot of material about how "we should not" understand things!?

In addition to all this, the philosophical heritage of the extremely problematic national origins, the "Hellenic" was promoted as a "natural theology" that led to divine revelation in the Lord and Savior of the world, Jesus Christ. Because of the modern Helleno-centric system of education of the broadest strata of Western societies, we understand today's need of the Greeks to see their heritage in natural continuity, like the tradition by which God himself led them to Christ!? This, we would say, teleological attitude (or understanding) comes from a perspective from which, on the basis of Christian purpose and goal, one can justify only limited aspects of one's former heritage that are now embedded in the Christian way of existence. We do not understand, however, that the reason behind this same rule does not apply to other nations. How come other peoples" "barbaric" beliefs are be tolerated as "natural theology" by Hellenic authors? Do not the foundations of the same so-called natural theologies apply to all peoples who have built their own traditions into their Christian ethos? In any case, if philosophy were really the "natural theology" that led Hellenes to Christ, it would be worthwhile to fundamentally determine oneself regarding the individual elements of such divine Providence.

Finally, ideological diversity in the teachings of ancient philosophers is not difficult to recognize as a non-cohesive set of opinions (ideas) united now under the ideological-national phrase "Hellenic Philosophy", which in each of its individual aspects testifies to complete ideological disharmony. What can then be said about the (in)compatibility of various philosophical ideas in the liturgicalsymbolic way of existence of the world as a Church? To add to the conundrum, modern educational systems begin with the story of the extraordinary appearance of philosophy, and then immediately proclaim the Christian truths that make up the spiritual and political roots of the modern world not only to be ideas taken from Platonists and Neoplatonists, but the same Platonic and Neoplatonic teachings to be the true foundations of the liturgical-symbolic way of existence of the Church.

In relation to all of the above, we believe that our ecclesiastical education lacks a comprehensive revision of the ideological views of ancient thought, insufficiently checked views i.e. views that were taken from those parts of the world that were historically hostile to our people in the centuries that are behind us. It seems as it was necessary to rein in our historical people's upsurge should have been curbed and completely replaced by the subordinating paradigm of Hellenic intoxication with its own enlightenment supremacy. In the time ahead, we must not forget that the Lord calls Himself by name The Truth which is why we need to draw a clear distinction between the philosopher as "someone who loves wisdom" per man, and the One, Holy, Conciliar and Apostolic Church that is comprised of people who love Truth Which is the Lord Jesus Christ Himself, the Saviour of the world. 
12 | Petrovic, P., Testimony of Eusebius of Caesarea on the origin of hellenic philosophy

\section{Sources}

Diogenes Laertius (1972). Lives of Eminent Philosophers. Cambridge - Massachusetts: Harvard University Press.

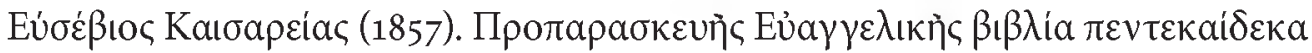
In J. P. Migne (ed.), Patrologiae Cursus Completus. Series Graeca [=PG]. Vol. 21. Paris.

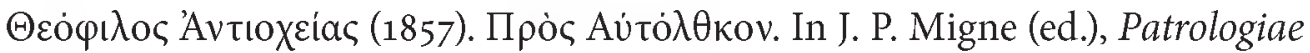
Cursus Completus. Series Graeca [=PG]. Vol. 6. Paris.

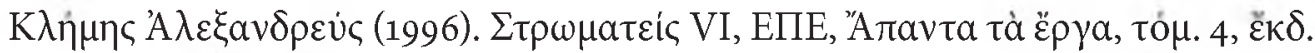

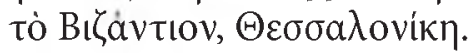

Plato (1903). Timaeus. In J. Burnet (ed.), Platonis Opera t. IV (17-105). Oxford University Press.

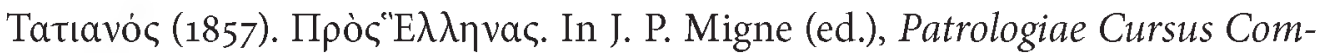
pletus. Series Graeca [=PG]. Vol. 6. Paris.

\section{Bibliography}

Forsdyke, E. J. (1956). Greece before Homer. London: Max Parrish.

Graves, R. (1955). The Greek Myths. Harmondsworth-Middlesex-London: Penguin Books Ltd. Прòs.

Ђукановић, А. (2012). Мозаик йрошлостии. Београд: БИГЗ.

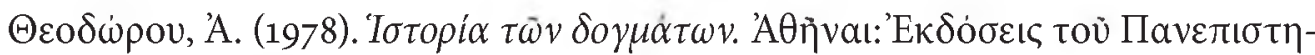

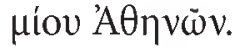

Levy-Strauss, C. (1991). Totemism. London: Merlin Press (f. e. 1964. reprint 1991). Marshall, J. (1891). A Short History of Greek Phylosophy. London: Percival \& Co. Петровић, П. (2007). Сведочанства Климента Александријског о пореклу древне јелинске мисли. Ойачник, I, 91-105.

Петровић, П. (2020). Историјска утемељеност јелинске митологије. Наслеbe, 46, 157-170.

Segal, R. A. (2002). Myth as Primitive Philosophy. In K. Schilbrack (ed.), Thinking Through Myths (Philosophical Perspectives) (26-44). London - New York: Routledge.

Zeleke, S. A. (2019). The Break and Continuity of Myth in Heraclitus's Philosophy. Global Scientific Journal, 7/11, 168-191.

Zeller, E. (1881). A History of Greek Philosophy (from the Earliest Period to the Time of Socrates) Vol. 1. London: Green and Co.

Zhu, R. (2005). Myth and Philosophy: From a Problem in Phaedo. Journal of the American Academy of Religion, 73/2, 453-473. 


\title{
Предраг Петровић
}

Универзитет у Београду, Православни богословски факултет, Београд

\section{Сведочанство Јевсевија Кесаријског о настанку јелинске философије}

\begin{abstract}
$\prod^{\mathrm{p}}$ ридев јелински представља уобичајену националну одредницу за свеукупну философску мисао античког света. Посвећеност Јелина записивању философских мисли као и историјских догађаја фасцинантна је, али и дубоко проблематична. Примећујемо у том смислу да су се антички писци неупоредиво више него официјелни представници данашње науке позабавили управо оригиналношћу тзв. јелинске мисли уопште. У списима Јевсевија Кесаријског наилазимо на нарочиту посвећеност овој теми, због чега наводимо управо његова сведочанства сабрана не само из хришћанских списа, већ и из философских извора и предања још увек живих у његовом времену. Из приложеног можемо закључити да се придев јелински може довести у питање при коначном одређењу порекла основних философских начела антике. Сматрамо корисним да у нашем времену укажемо на проблематично коришћење синтагме јелинска философија као на одомаћени terminus tehnicus (попут оног, „стари Грци“). У позадини поменуте синтагме препознајемо сада већ вишевековни покушај наметања одређене животне парадигме у покушају промене животне оријентације и у нашем народу. У овом историјском тренутку када је христолошка парадигма постојања на најозбиљнијем испиту морамо бити свесни сваке духовне и историјске промене настале као последица наше недовољне црквености која је кроз образовни систем отворила пут недовољно провереним „чињеницама“ о Богу, човеку и о свету који нас окружује.
\end{abstract}

Key words: философија, мит, Јелини, Орфеј, Афродита, Египат, Вавилон, град-држава.

Датум пријема чланка: 22. о9. 2021.

Датум прихватања чланка за објављивање: 09. 11. 2021. 